\title{
RPL5 Gene
}

National Cancer Institute

\section{Source}

National Cancer Institute. RPL5 Gene. NCI Thesaurus. Code C107652.

This gene plays a role in ribosome assembly. 